\title{
The burden of cancer risk in Canada's indigenous population: a comparative study of known risks in a Canadian region
}

This article was published in the following Dove Press journal:

International Journal of General Medicine

18 October 2011

Number of times this article has been viewed

\author{
Brenda Elias' \\ Erich V Kliewer ${ }^{1-3}$ \\ Madelyn Hall' \\ Alain A Demers ${ }^{1,2}$ \\ Donna Turner ${ }^{1,2}$ \\ Patricia Martens' \\ Say P Hong' \\ Lyna Hart ${ }^{4}$ \\ Caroline Chartrand ${ }^{5}$ \\ Garry Munro ${ }^{4}$ \\ 'Faculty of Medicine, Department \\ of Community Health Sciences, \\ University of Manitoba, Winnipeg, \\ MB, Canada; ${ }^{2}$ CancerCare Manitoba, \\ Winnipeg, MB, Canada; ${ }^{3}$ British \\ Columbia Cancer Agency, Vancouver, \\ BC, Canada; ${ }^{4}$ Assembly of Manitoba \\ Chiefs Health Information Research \\ Governance Committee, Winnipeg, \\ $\mathrm{MB}$, Canada; ${ }^{5}$ Manitoba First Nations \\ Diabetes Integration Project, \\ Winnipeg, MB, Canada
}

Background: Canadian First Nations, the largest of the Aboriginal groups in Canada, have had lower cancer incidence and mortality rates than non-Aboriginal populations in the past. This pattern is changing with increased life expectancy, a growing population, and a poor social environment that influences risk behaviors, metabolic conditions, and disparities in screening uptake. These factors alone do not fully explain differences in cancer risk between populations, as genetic susceptibility and environmental factors also have significant influence. However, genetics and environment are difficult to modify. This study compared modifiable behavioral risk factors and metabolic-associated conditions for men and women, and cancer screening practices of women, between First Nations living on-reserve and a non-First Nations Manitoba rural population (Canada).

Methods: The study used data from the Canadian Community Health Survey and the Manitoba First Nations Regional Longitudinal Health Survey to examine smoking, binge drinking, metabolic conditions, physical activity, fruit/vegetable consumption, and cancer-screening practices.

Results: First Nations on-reserve had significantly higher rates of smoking $(P<0.001)$, binge drinking $(P<0.001)$, obesity $(P<0.001)$ and diabetes $(P<0.001)$, and less leisure-time physical activity $(P=0.029)$, and consumption of fruits and vegetables $(P<0.001)$. Sex differences were also apparent. In addition, First Nations women reported significantly less uptake of mammography screening $(P<0.001)$ but similar rates for cervical cancer screening.

Conclusions: Based on the findings of this retrospective study, the future cancer burden is expected to be high in the First Nations on-reserve population. Interventions, utilizing existing and new health and social authorities, and long-term institutional partnerships, are required to combat cancer risk disparities, while governments address economic disparities.

Keywords: indigenous population, cancer risk, health behaviors, metabolic diseases, cancer screening

\section{Introduction}

First Nations are the largest Aboriginal group in Canada, comprising 64\% of the Aboriginal population, which along with the Inuit and Métis number more than one million people. While First Nations people live in urban, rural, and remote areas of the country, First Nation communities are generally located on land designated as reserves. ${ }^{1}$ Historically, Canadian First Nations have had a much lower cancer incidence and mortality rate than non-Aboriginal populations for all cancers combined and specific sites, except for gallbladder, kidney, and cervix. ${ }^{2-7}$ This rather positive picture of First Nations, relative to the non-Aboriginal population, has changed nationally and regionally. For the period 1984-1988, the national age-adjusted cancer mortality rate
Correspondence: Brenda Elias Faculty of Medicine, Department of Community Health Sciences, University of Manitoba, 750 Bannatyne Avenue, Winnipeg, MB, Canada R3L OH4

Tel +l 2047893358

Fax+l 2049757783

Email elias@ms.umanitoba.ca 
was $40 \%$ lower in Canadian First Nations population than the general population. Between 1979 and 1993, however, the national cancer mortality rate had increased for First Nations females (1.7\% per year) and for First Nations males $(6.2 \%$ per year). ${ }^{8}$ By the next decade (1991-2001), cancer was the third leading cause of death for First Nations males and the second leading cause for First Nations females. ${ }^{9}$ Regionally, there was a four-fold increase in the age-standardized cancer incidence rate for Saskatchewan First Nations from 1967-1971 to $1982-1986$ (59.4 to 249.3 per 100,000 ), while the rate only doubled in the overall Saskatchewan population. ${ }^{6}$ In Manitoba, the increase in cancer incidence among First Nations was less substantial (7\%) for the period 1972-1991. Cancer mortality, however, had increased by $50 \%$ for First Nations males $(130.0 / 100,000)$ and First Nations females (117.4/100,000), and specifically for such cancers as colorectal (55\%), lung (68\%), cervix (93\%), and gallbladder (95\%). ${ }^{10}$ For 1968-1991, cancer incidence for Ontario First Nations also increased for all cancers combined, and for the four most common cancers (breast, prostate, lung, and colorectal). The most dramatic increase was colorectal cancer for both First Nations men (risk ratio [RR]: 0.38 to 0.74 ) and women (RR: 0.29 to 0.78 ), which surpassed the general Ontario population rate. ${ }^{11}$ In Quebec, cancer incidence and mortality for the period 1988-2004 among residents of Indian reserves and northern villages had also increased to approximate the general Quebec population, with some sites higher for aboriginal men (liver, lung, and kidney) and aboriginal women (colorectal, lung, cervix, and kidney). ${ }^{12}$ Cancer incidence and mortality had also increased among the indigenous populations in the United States, ${ }^{13,14}$ Australia, ${ }^{15-18}$ New Zealand,,${ }^{19,20}$ and other Polynesian Islands. ${ }^{21}$

While genetic susceptibility, epigenetics, and the environment ${ }^{22-24}$ may account for some increased risk in some populations, individual behaviors, health status, and poor access to health-screening services tend to account for most of the risk. Smoking (and smoking duration), for instance, increases the risk for trachea, bronchus, lung, and larynx cancers. Smoking has also been associated with gastrointestinal and urinary cancers. ${ }^{25}$ Smoking risk has either been confounded (lung, oral cavity, pharynx, pancreas) or modified (larynx, esophagus, stomach) by heavy alcohol consumption. Heavy drinking, depending on the quantity of beer or spirits (vs wine) consumed, may also put drinkers at greater risk for oral cavity, pharynx, stomach cancers, large bowel, or pancreatic cancer. ${ }^{26}$ Diabetes mellitus may increase the risk of several cancers, ${ }^{27}$ such as pancreatic, ${ }^{28}$ liver, ${ }^{29}$ bladder, ${ }^{30}$ colon, ${ }^{31}$ prostate, ${ }^{32}$ breast, ${ }^{33}$ and endometrial. ${ }^{34}$ Research has shown that cancer patients with pre-existing diabetes tend to have a higher risk of all-cause mortality than individuals without diabetes. ${ }^{35} \mathrm{~A}$ direct association between the pathogenesis of hypertension and cancer has been prospectively demonstrated, as these disorders share epidemiological factors and pathophysiological pathways, tend to increase with ageing, ${ }^{36}$ and are influenced by alcohol consumption, smoking, and obesity (ie, elevating blood pressure and malignancy). ${ }^{37}$ Obesity has also been independently associated with esophageal, colon, rectum, thyroid, kidney, breast, and endometrial cancer. ${ }^{38}$ The risk can differ by gender and race/ethnicity. ${ }^{39}$ Recently, a relationship between obesity, as a component of metabolic syndrome, and colorectal cancer has been proposed. ${ }^{40}$ Obesity, hypertension, dyslipidemia, and insulin resistance (or established diabetes), when occurring together, may accelerate the onset of esophagus, gastric cardia, colorectal, and renal cell cancer. ${ }^{41}$ Physical inactivity and limited consumption of healthy foods has also been shown to contribute to this complex risk trajectory. ${ }^{42,43}$ The reverse is also true. Increased physical activity may modify metabolic hormones and growth factors, lower insulin, glucose, and triglycerides, raise HDL cholesterol, and lower cancer risk. $^{44}$

Cancer screening availability and uptake has also influenced cancer rates. Mammography screening has reduced cancer mortality among older women aged 50-74 years. ${ }^{45}$ Poor access to mammography and inadequate cervical screening programs, however, have contributed to higher rates of cancer mortality among women of lower socioeconomic status and from certain race/ethnicity groups. ${ }^{46}$

CancerCare Manitoba, a health organization that also maintains the Manitoba Cancer Registry, has recently reported standardized cancer incidence rates of 457.8 per 100,000, and standardized mortality rates of 209.1 per $100,000 .{ }^{47}$ It is hypothesized that the number of new cancer cases has increased at a rate of approximately $2 \%$ each year due to population growth, an aging population, and an increase in risk factors. ${ }^{48}$ Currently, a team of researchers in Manitoba has partnered with First Nations to address these increasing rates. To date, however, no study has yet investigated individual and clustered risk comparatively with a Canadian First Nation on-reserve population. This study is the first to investigate, by gender, modifiable behavioral factors, metabolic-associated conditions (individually and as clusters), and cancer screening practices (women) between 
First Nations living on-reserve and a rural population in the Province of Manitoba (Canada).

\section{Materials and methods Data sources}

This study draws on two different surveys to compare cancer risk factors between First Nations on-reserve and other rural Manitoban adults: the Canadian Community Health Survey (2003) and the Manitoba First Nations Regional Longitudinal Health Survey for adults (2002/03). These two surveys occurred at nearly the same time, represent co-existing but distinct samples, and provide similar measures. Together, these datasets provide good measures for a comparative analysis of cancer risk between a First Nations on-reserve population and a rural, non-Aboriginal population in Canada, and Manitoba specifically.

The Canadian Community Health Survey is a crosssectional community survey conducted by Statistics Canada in order to provide a profile of the health status, health care utilization, and health determinants of the Canadian population. The Canadian Community Health Survey Cycle 2.1 (2003) public use file included a sample of approximately $98 \%$ of the Canadian population aged 12 years or older. Sample units selected from the telephone list frame were interviewed from centralized call centres using computerassisted interviewing (CATI). This survey excluded First Nations reserve communities, First Nations living on Crown lands, as well as residents of institutions, full-time members of the Canadian Forces and residents of certain remote regions. A sub-sample of rural area Manitobans aged 20 and older was drawn from the publicly available micro data file $(\mathrm{N}=4687)$.

The Manitoba First Nations Regional Longitudinal Health Survey for adults aged 18 years and older was conducted in 2002/2003 on Manitoba First Nation reserve communities, which represent a predominately rural First Nations population. At that time the federal department of Indian and Northern Affairs reported that there were 113,264 registered First Nations in Manitoba, with 54.6\% living on reserves. The survey involved a multistage stratified random sampling approach to select a representative sample of Manitoba on-reserve First Nations communities. Small (population < 500), medium (population 500-999), and large communities (population $>1000$ ) were randomly selected from seven Tribal Council regions. The adult survey was implemented in 27 communities, and the community sample was stratified by age and gender. In each community, interviewers randomly selected households and interviewed, where possible, two adults living in the household (one male and one female) and all adults aged 55 years and older. The adult survey achieved a response rate of $77 \%$, with $60 \%$ of the communities achieving a response rate of over $80 \%$. The adult survey sample abstracted for this paper includes women and men aged 20 years and older $(\mathrm{N}=2931)$.

\section{Definition of variables}

Comparable variables were selected from each survey to describe the demographic characteristics, behavioral risk factors, and cancer-screening practices of each subsample. The surveys were conducted at approximately the same time, but were targeted for different populations and had separate goals. Therefore, the two surveys were distinct, necessitating that values on some variables be collapsed in order to ensure that the final measures were as similar as possible.

Demographic and economic variables abstracted to describe the samples included age groups (20-34 years, 35-49 years, and 50 years and older), gender (male, female), marital status (married or living common-law, single, widowed/ separated/divorced), education (less than complete high school, completed high school or the equivalent, or higher), annual household income $(<\$ 15,000, \$ 15,000-\$ 29,999$, $\$ 30,000+$, not stated [all amounts in CAD]), and employment (yes, currently employed or self-employed). We examined the prevalence of smoking (self-reported current smoker "daily" or "occasionally") and alcohol consumption defined as self-reported binge drinking of five or more drinks, daily or at least 2-3 times per month. Another relevant variable assessed was body mass index (BMI) to describe those who were overweight (BMI $\geq 25<30$ ) or obese (BMI $\geq 30$ ). To assess metabolic risk, we added values indicating obesity (BMI $\geq 30$ ), diabetes, and hypertension status ("have you ever been told by a health care provider that you have ... 'diabetes'... 'hypertension"') into one variable to identify individuals with one, two, or all three conditions vs none. We also investigated positive practices often recommended to lower cancer risk, such as daily consumption of fruits and vegetables assessed by positive responses to any combination of fresh, frozen, or canned fruits and vegetables eaten once or several times a day. A lack of physical activity was assessed by different questions on the two surveys. The Manitoba First Nations Regional Longitudinal Health Survey question asked: "In a typical week, how much time do you participate in any kind of physical activity (at work, school, home, or leisure), which results in an increase in your heart rate and breathing?" 
We used the response coded as "none". The Canadian Community Health Survey asked for responses from a list of 22 activities and sports not related to work (ie, leisure time activities), done over the past 3 months. The list included activities such as walking for exercise, yard work, golf, dancing, fishing, and soccer: "Have you done any ... in the past three months?". We used the response coded "no physical activity". Screening practices of women, specifically having a Pap test within the past 3 years and mammography within the past 5 years for women 50 years and older, were also examined. While biennial mammography screening is typically recommended, a 5-year period was used in this study due to the possibility of limited access to screening facilities in rural and remote reserve communities. The screening questions, however, did not ask why women had the tests, so that these questions were not a direct measure of routine screening for these cancers. Screening practices for First Nations men, such as prostate cancer screening, were not available in the survey data.

\section{Data weighting and analyses}

The two data sources included weights to adjust for sampling differences in order to produce estimates representative of the covered population. SUDAAN software (v 10; Research Triangle Institute, Research Triangle Park, NC) was used to calculate weighted prevalence estimates and 95\% confidence intervals. A ratio statistic (Manitoba First Nation Regional Longitudinal Health Survey/Canadian Community Health Survey) was calculated to assist in comparing the two samples, and a two-proportion $Z$-test statistic ascertained whether the proportion differences were statistically significant at $P \leq 0.05$.

\section{Results}

\section{Sample sociodemographic characteristics}

The sociodemographic characteristics of the Manitoba First Nations living on-reserve and the rural Manitoba population are shown in Table 1. First Nations living on-reserve were younger, with $39.6 \%$ under the age of 35 compared to $24.1 \%$ in rural Manitoba communities $(P<0.001)$, while the rural Manitoba population had twice as many individuals aged 50 and over (45.1\% vs $20.3 \%, P<0.001)$. The rural Manitoba population had a greater proportion of individuals who were married or living common law $(72.8 \%$ vs $51.7 \%, P<0.001)$, whereas the First Nations population had a considerably higher number of single unmarried individuals $(34.9 \%$ vs $15.2 \%$ in the rural Manitoba population, $P<0.001$ ), which is consistent with a younger population.

The First Nations on-reserve population had a far higher proportion of individuals who had not completed high school (62.9\% vs 30.6\% in the rural Manitoba population, $P<0.001)$. Correspondingly, both household income levels and employment were lower in the First Nations population. However, fewer First Nations reported an income (47.1\% not stated vs $17.4 \%$ among the rural Manitoba subsample, $P<0.001$ ). Of those who reported an income, three times as many First Nations individuals lived in households with annual incomes of less than $\$ 15,000$ compared with the rural Manitoba population ( $21.4 \%$ vs $6.8 \%$ respectively, $P<0.001$ ),

Table I Social demographic characteristics

\begin{tabular}{|c|c|c|c|c|c|c|c|c|}
\hline \multirow[t]{2}{*}{ Social demographics } & & \multicolumn{2}{|c|}{$\begin{array}{l}\text { MFNRLHS }^{a} \\
(N=293 I) \\
\end{array}$} & \multicolumn{2}{|c|}{$\begin{array}{l}\mathrm{CCHS}^{\mathrm{b}} \\
(\mathrm{N}=4687) \\
\end{array}$} & \multirow[t]{2}{*}{$|\mathbf{Z}|$} & \multirow[t]{2}{*}{$P$ value } & \multirow{2}{*}{$\begin{array}{l}\text { Ratio } \\
\text { (MFNRLHS/ } \\
\text { CCHS) }\end{array}$} \\
\hline & & $\%$ & $95 \% \mathrm{Cl}$ & $\%$ & $95 \% \mathrm{Cl}$ & & & \\
\hline Age & $20-34$ & 39.6 & $35.6-43.8$ & 24.1 & $22.4-25.9$ & 7.24 & $<0.001$ & 1.64 \\
\hline \multirow[t]{2}{*}{$n^{\mathrm{a}}=293 I n^{\mathrm{b}}=4687$} & $35-49$ & 40.1 & $36.4-44.0$ & 30.8 & $28.8-32.8$ & 4.44 & $<0.001$ & 1.30 \\
\hline & $50+$ & 20.3 & 17.9-22.9 & 45.1 & $43.2-47.0$ & 16.01 & $<0.00$ I & 0.45 \\
\hline Gender & Male & 48.5 & $46.6-50.5$ & 50.0 & $48.0-52.0$ & 1.04 & 0.300 & 0.97 \\
\hline$n^{a}=2931 n^{b}=4687$ & Female & 51.5 & $49.5-53.4$ & 50.0 & $48.0-52.0$ & 1.04 & 0.300 & 1.03 \\
\hline Marital status & Married/common-law & 51.7 & $48.7-54.7$ & 72.8 & $71.1-74.4$ & 12.53 & $<0.001$ & 0.71 \\
\hline \multirow[t]{2}{*}{$n^{a}=2908 n^{b}=4663$} & Single & 34.9 & $32.1-37.8$ & 15.2 & $13.7-16.7$ & 12.72 & $<0.001$ & 2.30 \\
\hline & Widowed/separated/divorced & 13.4 & II.8-15.| & 12.0 & $11.1-13.0$ & 1.44 & 0.149 & 1.12 \\
\hline Education & $<$ High school & 62.9 & $58.9-66.7$ & 30.6 & $28.8-32.4$ & 15.58 & $<0.001$ & 2.06 \\
\hline$n^{a}=2850 n^{b}=4591$ & High school/equivalent & 37.1 & $33.3-41.1$ & 69.4 & $67.6-71.2$ & 15.58 & $<0.001$ & 0.53 \\
\hline Household income & $<\$ 15,000$ & 21.4 & I7.7-25.7 & 6.8 & $6.0-7.7$ & 7.37 & $<0.001$ & 3.15 \\
\hline \multirow[t]{3}{*}{$n^{a}=2919 n^{b}=4687$} & $\$ 15,000-\$ 29,999$ & 14.2 & $11.7-17.2$ & 13.9 & $12.7-15.2$ & 0.24 & 0.810 & 1.02 \\
\hline & $\$ 30,000+$ & 17.3 & $|4.7-20|$. & 62.0 & $60.1-63.8$ & 27.87 & $<0.001$ & 0.28 \\
\hline & Not stated & 47.1 & $41.6-52.7$ & 17.4 & $16.0-18.9$ & 10.67 & $<0.001$ & 2.71 \\
\hline Employed & Yes & 43.8 & $40.4-47.3$ & 71.1 & $69.4-72.8$ & 14.58 & $<0.001$ & 0.62 \\
\hline
\end{tabular}

Notes: aManitoba First Nations Regional Longitudinal Health Survey (MFNRHS); ' Canadian Community Health Survey (CCHS). 
while more than three times as many rural Manitoba individuals lived in households with annual incomes of $\$ 30,000$ or greater compared with the First Nations population ( $62.0 \%$ vs $17.3 \%$, $P<0.001)$. As well, a greater proportion of rural Manitoba individuals were employed $(71.1 \%$ vs $43.8 \%$ of First Nations on-reserve individuals, $P<0.001)$.
Modifiable health behaviors, health status, and health-promoting factors

Summarized in Table 2 are modifiable health behaviors, health status, and health-promoting factors of the First Nations on-reserve population and the rural Manitoba population. Smoking among the First Nations on-reserve

Table 2 Health risk behaviors, health status and health promoting factors

\begin{tabular}{|c|c|c|c|c|c|c|c|c|}
\hline & \multirow[t]{2}{*}{ Gender } & \multicolumn{2}{|c|}{$\begin{array}{l}\text { MFNRLHS }^{a} \\
(N=293 I)\end{array}$} & \multicolumn{2}{|c|}{$\begin{array}{l}\text { CCHS }^{b} \\
(N=4687)\end{array}$} & \multirow[t]{2}{*}{$|\mathbf{Z}|$} & \multirow[t]{2}{*}{$P$ value } & \multirow{2}{*}{$\begin{array}{l}\text { Ratio } \\
\text { (MFNRLHS/ } \\
\text { CCHS) }\end{array}$} \\
\hline & & $\%$ & $95 \% \mathrm{Cl}$ & $\%$ & $95 \%$ & & & \\
\hline Several servings/day of fruit and & $\mathrm{F}$ & 28.3 & $25.1-3 \mid .8$ & 39.8 & $37.2-42.6$ & 5.39 & $<0.001$ & $0.7 \mathrm{I}$ \\
\hline vegetables & $M$ & 22.1 & $18.3-26.5$ & 25.0 & $22.6-27.7$ & 1.22 & 0.223 & 0.88 \\
\hline$n^{a}=2742 n^{b}=4295$ & Total & 25.4 & $22.5-28.4$ & 32.5 & $30.6-34.4$ & 4.14 & $<0.001$ & 0.78 \\
\hline No leisure-time physical activity & $\mathrm{F}$ & 18.8 & $14.0-24.8$ & 10.4 & $8.9-12.2$ & 3.09 & 0.002 & $\mathrm{I} .8 \mathrm{I}$ \\
\hline \multirow[t]{2}{*}{$n^{a}=2051 n^{b}=4584$} & $M$ & 9.4 & $6.6-13.3$ & 9.6 & $8.1-I I .4$ & 0.11 & 0.914 & 0.98 \\
\hline & Total & 14.2 & $10.8-18.5$ & 10.0 & $8.9-11.2$ & 2.18 & 0.029 & 1.42 \\
\hline Overweight & $\mathrm{F}$ & 31.6 & $27.1-36.6$ & 30.7 & $28.3-33.2$ & 0.36 & 0.716 & 1.03 \\
\hline \multirow[t]{2}{*}{$n^{a}=2271 n^{b}=4458$} & $M$ & 41.6 & $37.3-46.1$ & 44.9 & $42.0-47.9$ & 1.26 & 0.208 & 0.93 \\
\hline & Total & 36.7 & $33.5-40.0$ & 38.1 & $36.1-40.0$ & 0.71 & 0.475 & 0.96 \\
\hline Obese & $\mathrm{F}$ & 41.7 & $37.3-46.2$ & 20.4 & $18.4-22.6$ & 8.88 & $<0.001$ & 2.04 \\
\hline \multirow[t]{2}{*}{$\mathrm{n}^{\mathrm{a}}=227 \mathrm{I} \mathrm{n}^{\mathrm{b}}=4458$} & $M$ & 33.5 & $28.9-38.5$ & 22.9 & $20.4-25.6$ & 4.00 & $<0.001$ & 1.46 \\
\hline & Total & 37.5 & $33.7-41.5$ & 21.7 & $20.0-23.4$ & 7.64 & $<0.001$ & $\mathrm{I} .73$ \\
\hline Binge drinking & $\mathrm{F}$ & 27.5 & $23.4-32.0$ & 4.0 & $3.1-5.2$ & 10.99 & $<0.001$ & 6.88 \\
\hline \multirow[t]{2}{*}{$n^{a}=2533 n^{b}=4622$} & $M$ & 39.6 & $35.5-43.8$ & 17.7 & $15.4-20.2$ & 9.42 & $<0.001$ & 2.24 \\
\hline & Total & 33.5 & $30.4-36.8$ & 10.8 & $9.5-12.3$ & $13.4 \mid$ & $<0.001$ & 3.10 \\
\hline Smoking & $\mathrm{F}$ & 68.4 & $62.9-73.5$ & 22.1 & 19.9-24.4 & 16.65 & $<0.001$ & 3.10 \\
\hline \multirow[t]{2}{*}{$n^{a}=2837 n^{b}=4677$} & $M$ & 67.6 & $61.8-72.8$ & 27.8 & $25.1-30.6$ & 13.27 & $<0.001$ & 2.43 \\
\hline & Total & 68.0 & $62.8-72.8$ & 24.9 & $23.2-26.7$ & 16.79 & $<0.001$ & 2.73 \\
\hline Diabetes & $\mathrm{F}$ & 29.0 & $25.7-32.5$ & 4.7 & $3.9-5.8$ & 14.39 & $<0.001$ & 6.17 \\
\hline \multirow[t]{2}{*}{$n^{a}=2661 n^{b}=4684$} & $M$ & I5.I & $12.0-18.8$ & 7.3 & $6.0-8.9$ & 4.39 & $<0.001$ & 2.07 \\
\hline & Total & 22.4 & |9.9-25.| & 6.0 & $5.2-7.0$ & 12.30 & $<0.001$ & 3.73 \\
\hline Hypertension & $\mathrm{F}$ & 19.0 & 15.8-22.7 & 19.3 & $|7.5-2| .2$ & 0.13 & 0.893 & 0.98 \\
\hline \multirow[t]{2}{*}{$n^{a}=2724 n^{b}=4677$} & $M$ & 13.4 & $10.6-16.8$ & 16.0 & $|4|-.|8|$. & $\mathrm{I} .44$ & 0.150 & 0.84 \\
\hline & Total & 16.3 & |3.7-19.3 & 17.6 & $16.3-19.0$ & 0.88 & 0.378 & 0.93 \\
\hline \multirow{2}{*}{\multicolumn{9}{|c|}{$\begin{array}{l}\text { Combined metabolic risk: } \\
\qquad n^{\mathrm{a}}=2016 \mathrm{n}^{\mathrm{b}}=4447\end{array}$}} \\
\hline & & & & & & & & \\
\hline Any one of obese, diabetes, or & $\mathrm{F}$ & 35.8 & $30.4-41.7$ & 25.7 & $23.5-28.1$ & 3.43 & $<0.001$ & 1.39 \\
\hline \multirow[t]{2}{*}{ hypertension } & $M$ & 28.5 & $24.6-32.7$ & 25.9 & $23.3-28.6$ & I.II & 0.266 & 1.10 \\
\hline & Total & 32.2 & $28.4-36.2$ & 25.8 & $24.1-27.6$ & 3.05 & 0.002 & 1.25 \\
\hline Any two of obese, diabetes, or & $\mathrm{F}$ & 16.5 & $13.7-19.8$ & 6.9 & $5.9-8.1$ & 6.06 & $<0.001$ & 2.39 \\
\hline \multirow[t]{2}{*}{ hypertension } & $M$ & 10.8 & $8.5-13.7$ & 7.7 & $6.3-9.4$ & 2.12 & 0.034 & 1.40 \\
\hline & Total & 13.7 & | I.8-|5.8 & 7.3 & $6.4-8.4$ & 5.91 & $<0.001$ & 1.88 \\
\hline \multirow[t]{3}{*}{ Obese, diabetes, and hypertension } & $\mathrm{F}$ & 6.6 & $5.0-8.8$ & 1.8 & $1.2-2.7$ & 4.88 & $<0.001$ & 3.67 \\
\hline & $M$ & 5.0 & $3.2-7.8$ & 1.6 & $1.1-2.4$ & 2.98 & 0.003 & 3.13 \\
\hline & Total & 5.8 & $4.4-7.7$ & 1.7 & $1.3-2.3$ & 4.91 & $<0.001$ & 3.41 \\
\hline \multicolumn{9}{|l|}{ Combined smoking/binge drinking } \\
\hline \multicolumn{9}{|l|}{$\mathrm{n}^{\mathrm{a}}=25 \mathrm{II} \mathrm{n}^{\mathrm{b}}=4621$} \\
\hline \multirow[t]{3}{*}{ Any one of smoking or binge drinking } & $\mathrm{F}$ & 50.3 & $45.0-55.7$ & 21.1 & $19.0-23.3$ & 10.46 & $<0.001$ & 2.38 \\
\hline & $M$ & 46.5 & $40.5-52.5$ & 29.2 & $26.5-32.0$ & 5.38 & $<0.001$ & 1.59 \\
\hline & Total & 48.4 & $43.4-53.4$ & 25.1 & $23.4-26.9$ & 9.05 & $<0.001$ & 1.93 \\
\hline \multirow[t]{3}{*}{ Both smoking and binge drinking } & $\mathrm{F}$ & 22.1 & |8.6-26.| & 2.5 & $1.7-3.5$ & 10.55 & $<0.001$ & 8.84 \\
\hline & M & 30.0 & $26.5-33.7$ & 8.1 & $6.4-10.2$ & 11.09 & $<0.001$ & 3.70 \\
\hline & Total & 26.0 & $23.2-29.1$ & 5.3 & $4.3-6.4$ & $13.8 \mid$ & $<0.001$ & 4.91 \\
\hline
\end{tabular}

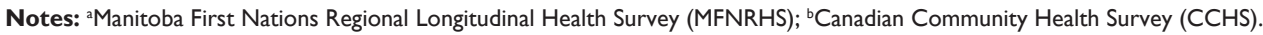


population was more than 2.5 times greater than among the rural Manitoba population $(68.0 \%$ vs $24.9 \%, P<0.001)$. Binge drinking was much higher among the First Nations population $(33.5 \%$ vs $10.8 \%, P<0.001)$ than in the rural Manitoba population. For combined risk, twice as many First Nations, as opposed to the rural Manitoba population (48.4\% vs $25.1 \%$ ), $P<0.001$, were either smokers or binge drinkers. Nearly five times as many First Nations (26\%) than rural Manitobans (5.3\%) engaged in both smoking and binge drinking $(P<0.001)$. Within gender, more than eight times as many First Nations females than rural Manitoba females $(22.1 \%$ vs $2.5 \%, P<0.001)$, and three times more First Nations men than rural Manitoba men (30\% vs $8.1 \%$, $P<0.001)$ were both smokers and binge drinkers.

In terms of BMI, being overweight was similar between the First Nations and rural Manitoba populations (36.7\% vs $38.1 \%$ respectively), regardless of gender. A difference, however, was apparent for obesity. The prevalence of obesity was higher among First Nations males than rural Manitoba males (33.5\% vs 22.9\%, $P<0.001)$, higher for First Nations females than rural Manitoba females (41.7\% vs $20.4 \%, P<0.001)$ and higher among First Nations females than First Nations males (41.75 vs 33.5\%, f/m ratio = 1.25). For diabetes, the rates were nearly six times higher among First Nations women as opposed to rural Manitoba women (29.0\% vs $4.7 \%, P<0.001)$, and two times higher among First Nations men as opposed to rural Manitoba men (15.1 vs $7.3, P<0.001)$. No differences in hypertension rates were found between the First Nations and rural Manitoba populations, regardless of gender.

The proportion of First Nations females who were either obese or had diabetes or hypertension was greater than among the rural Manitoba women $(35.8 \%$ vs $25.7 \%, P<0.001)$. There was little difference between First Nations and rural Manitoba men (28.5\% vs 25.9\%, not significant). Differences were apparent for combined metabolic conditions. The estimates for any two of these conditions were two times greater among the First Nations women than rural Manitoba women $(16.5 \%$ vs $6.9 \%, P<0.001)$, and 1.4 times higher among First Nations men than rural Manitoba men (10.8\% vs $7.7 \%, P=0.034)$. The ratios increased significantly for those having a combination of all three conditions. Nearly four times more First Nations women reported having all three metabolic factors than rural Manitoba women $(6.6 \% \mathrm{vs}$ $1.8 \%, P<0.001)$, and three times more First Nations men than rural Manitoba men had all three conditions $(5.0 \%$ vs $1.6 \%, P=0.003)$. In the First Nations population, a consistent gender disadvantage was apparent for any one, any two, or all three conditions ( $\mathrm{f} / \mathrm{m}$ ratio: at least one $=1.26$ vs any two $=1.53$ vs all three $=1.32$ ). In the non-First Nations rural Manitoba population, a gender difference was less apparent for having all three conditions ( $\mathrm{f} / \mathrm{m}$ ratio: at least one $=0.99 \mathrm{vs}$ any two $=0.90$; all three $=1.13$ ).

As for health-promoting behaviors, the differences were greater for females. Only $28.3 \%$ of First Nations females reported consuming several servings of fruits and vegetables each day compared with $39.8 \%$ of rural Manitoba females $(P<0.001)$. An even greater percentage of First Nations females, as opposed to rural Manitoba females, reported having no leisure-time physical activity (18.8\% vs $10.4 \%, P=0.002$ ).

Cancer-screening behavior among women also varied between the study groups (Table 3). There was no difference in self-reported cervical cancer screening behaviors in the last 3 years among women age 20 years and older $(74.1 \%$ vs $76.7 \%$ ). The pattern, however, was quite different for uptake of mammography screening. The estimate for mammography within the past 5 years for First Nations women 50 years or older was $62.8 \%$ compared with $86.0 \%$ for rural Manitoba women of the same age $(P<0.001)$.

\section{Discussion}

This is the first study to investigate modifiable behavioral risk, metabolic risk, and cancer-screening uptake (women) among a First Nations on-reserve population, and a rural Manitoba population. The risk was greater for First Nations for all but

Table 3 Cancer screening behaviors

\begin{tabular}{|c|c|c|c|c|c|c|c|}
\hline \multirow[t]{2}{*}{ Screening behaviors } & \multicolumn{2}{|c|}{ MFNRLHS $^{a}$} & \multicolumn{2}{|c|}{$\mathrm{CCHS}^{\mathrm{b}}$} & \multirow[t]{2}{*}{$|\mathbf{Z}|$} & \multirow[t]{2}{*}{$P$ value } & \multirow{2}{*}{$\begin{array}{l}\text { Ratio } \\
\text { (MFNRLHS } \\
\text { CCHS) } \\
\end{array}$} \\
\hline & $\%$ & $95 \% \mathrm{Cl}$ & $\%$ & $95 \%$ & & & \\
\hline $\begin{array}{l}\text { Mammography for women } \geq 50 \text { years } \\
n^{a}=373 n^{b}=|| 3 \mid\end{array}$ & 62.8 & $53.5-71.2$ & 86.0 & $83.3-88.3$ & 5.16 & $<0.00 \mathrm{I}$ & 0.73 \\
\hline $\begin{array}{l}\text { Pap test in last } 3 \text { years (all women age } 20+\text { ) } \\
n^{\mathrm{a}}=1310 \mathrm{n}^{\mathrm{b}}=2327\end{array}$ & 74.1 & $70.7-77.2$ & 76.7 & $74.4-78.9$ & 1.34 & 0.179 & 0.97 \\
\hline
\end{tabular}

Notes: a Manitoba First Nations Regional Longitudinal Health Survey (MFNRHS); 'Canadian Community Health Survey (CCHS). 
three factors (hypertension, overweight, and having a Pap test in the last 3 years).

Smoking behavior was higher in the First Nations on-reserve population, compared with the rural Manitoba population. When compared nationally, however, rates for the Manitoba First Nations on-reserve population and rural Manitoba population both exceeded the national pattern (58.5\% First Nations vs 19\% all Canadians). ${ }^{49}$ Our findings were consistent with past research in the Manitoba First Nations population, ${ }^{50}$ as well as other regional Aboriginal populations when compared with non-Aboriginal populations. ${ }^{51}$ As supported by the literature, we found no gender differences for smoking behavior in either the Manitoba First Nations or the rural Manitoba population. ${ }^{52,53}$ The disproportionately high rate of heavy drinking in the First Nations population is also supported by past research in other Aboriginal populations. ${ }^{54,55}$ While assessing combined risk for cancer is common in cancer studies, no study has investigated this pattern in an Aboriginal population. By combining smoking and binge drinking, we found that First Nations onreserve, as opposed to the rural Manitoba population, had the highest rates, particularly among First Nations males.

Obesity rates were also higher in the Manitoba First Nations on-reserve population, particularly among First Nations women. These rates were dramatically higher than last recorded in $1997 .{ }^{50}$ Findings from several other studies conducted in other North American indigenous populations support this increasing burden of risk. ${ }^{56-60}$ Diabetes prevalence was also higher in the First Nations population, again among First Nations women, and this higher prevalence has been noted ${ }^{61-63}$ A surprising finding, however, was the similarity in hypertension rates between the populations. A difference was expected due to the higher rates of obesity, diabetes, and cardiovascular comorbidities in the First Nations population. The Public Health Agency of Canada suggests that approximately $5 \%$ of individuals do not report high blood pressure even when they are on medication, or they may not report thinking that their hypertension had been cured by prescribed medications or lifestyle modifications. ${ }^{64}$ The lack of difference could also be attributed to a lack of engagement with the health care system. A recent Canadian study suggested that while individuals already engaged in the health care system (women and individuals with a chronic conditions) were more likely to have their blood pressure checked, younger males and visible minorities (including Aboriginal) were less likely to have such screening tests, or did not believe it was necessary. ${ }^{65}$ As for self-reported metabolic clusters (obesity, hypertension, and diabetes), we demonstrated a higher rate in the First Nations on-reserve population. This finding is supported by diabetes studies conducted in southern and remote First Nations communities. ${ }^{60,66-68}$ Of concern is that recent clinical research suggests that First Nations children and adolescents are now meeting the metabolic syndrome criteria, ${ }^{69-73}$ and that such early onset, hypothetically, may increase the risk for cancer in the First Nations population.

First Nations, compared with the rural Manitoba population, were also less active in leisure-time physical activity which is supported by a recent region-specific study of northern Aboriginal and non-Aboriginal populations. ${ }^{51} \mathrm{We}$ should, however, be cautious in such interpretations due to the way physical activity is measured and analyzed, making it difficult to interpret across studies and across populations. As for healthy dietary patterns, we found that fewer First Nations women and First Nations men, compared with their rural Manitoba counterparts, were consuming several servings of fruits and vegetables per day. Poor uptake of healthy foods in First Nations communities may be due to food insecurity and poor access to healthy foods, especially among households with lower socioeconomic status. ${ }^{74}$ The relation of socioeconomic status (and food insecurity) to cancer, however, is both complex and dynamic at the individual and area level, so that making generalizations is difficult and potentially misleading. ${ }^{75}$

Despite this very bleak health risk profile, we have seen some positive change in the on-reserve First Nations population. In Manitoba, cervical cancer screening for First Nations women has historically been lower than the Manitoba average, despite this population's increased rate of cervical cancer. ${ }^{76}$ This study is the first to report that self-reported cervical screening practices among on-reserve First Nations women are now approximating that of the rural Manitoba population. Trends in other provinces suggest that the uptake of screening is a product of innovative programming. ${ }^{77}$ Our research, although based on self-reports, suggests that the target rate may have been met through such initiatives. A recent Manitoba sub-regional study, however, found that differences still exist. ${ }^{78}$ A broader, population-based, Manitoba study using administrative claims data had also shown that northern, isolated, and urban areas characterized by high deprivation continue to have lower rates, thus demonstrating a need for targeted programming and sub-regional surveillance. ${ }^{79}$ This study was not able to show First Nations vs non-First Nations differences as the investigators had no access to administrative data with a First Nations identifier. 
Our current research program, which has developed an identifier for these databases, will investigate whether these differences are due to First Nations access and uptake issues. The same will be done for mammography screening. In this study, mammography-screening behaviors for First Nations on-reserve women was much lower, while rural Manitoba women almost approximated their urban counterparts. ${ }^{80}$ This uptake disparity could largely be due to access issues. Efforts to expand breast-screening services in the north are underway in Manitoba. ${ }^{81}$ Some women, particularly older women and women living in northern-isolated communities characterized by high levels of deprivation, ${ }^{82,83}$ however, are still difficult to reach. ${ }^{84,85}$ We will investigate this further in an administrative data study.

While this study yielded important findings, it did have a number of limitations. For one, we relied on two distinct self-report datasets that share similar limitations and have separate shortcomings. The Canadian Community Health Survey included First Nations people living off-reserve, along with others defined as Aboriginal (Métis and Inuit). This combined group constituted $7.85 \%$ of the rural 20 years and older Manitoba sample. This subsample could not be excluded from the dataset because the visible minority flag was suppressed in the public use microdata file. While the Canadian Community Health Survey included some First Nations living off-reserve, the Manitoba First Nations Regional Longitudinal Health Survey surveyed only First Nations on-reserve. Additionally, questions were not worded the same across the two surveys, different sampling approaches were used, and the measures were based on self-reports. While research suggests that measures of self-reported diabetes and smoking tend to have more accuracy, other behavioral and health status measures do not. ${ }^{86}$ For both surveys, self-reported data may have underestimated the prevalence of binge drinking, overweight, obesity, screening behaviors, and overestimated the prevalence of physical activity and daily consumption of fruits and vegetables. As noted, self-reported hypertension is also prone to misclassification. In the two surveys, the physical activity measure was limited to leisure activities and did not measure activities performed at work, school, or home. Because of this limitation, we were not able to investigate potential confounding between leisure and work-related physical activity in the two populations (ie, individuals engaged in more physically active work may be less likely to engage in leisure time activities). Furthermore, the metabolic condition variable only summarized a cluster of self-reported metabolic conditions and is not a true measure of metabolic syndrome. Administrative data, such as hospital, physician, and pharmaceutical data, as well as laboratory data would have provided a more refined measure of metabolic conditions.

\section{Conclusions}

In summary, this study has confirmed that there is high behavioral and metabolic health risk in the First Nations on-reserve population. Uptake of cancer screening by First Nations women may have improved for cervical cancer but not for mammography. Such disparity as noted is evident in other Canadian indigenous populations, and has been documented internationally as well. In the United States, disparities in cancer risk factors, health status, and use of cancer screening tests persist between American Indian/ Alaska Natives and non-Hispanic whites. ${ }^{87}$ A comparative disparity study between New Zealand and the United States showed similar patterns for health status and modifiable risk behaviors for their indigenous populations. ${ }^{88}$ High cancer risk has also been noted in the Australian indigenous population. ${ }^{89,90}$ Our study, however, was the first to compare cancer risk, individually and as clusters, between a First Nations on-reserve population and rural non-First Nations Manitoban population.

While genetics and environment play a significant role in cancer risk, our findings confirm that future cancer burden is likely to be much higher in the Manitoba First Nations on-reserve population, relative to the rural Manitoba population, based on the modifiable behavioral risk factors we examined. Interventions targeting risk factors for chronic disease have resulted in short-term success when directed at First Nation children, families, and communities, as illustrated by the highly regarded Kanien'kehá:ka (Mohawk) community diabetes prevention program - the first launched in a Canadian First Nation community. Unfortunately, the benefits of the intervention were not realized over time due to life situations influenced by social, cultural, and political factors at various levels that are beyond local programs. ${ }^{91}$ While transferring individual lifestyle promotion programs to First Nations may be the most prudent action, what is really required is the full involvement of indigenous peoples in primary health care and in planning and implementing health protection programs, at the local and national level. ${ }^{92}$ Indeed, such national and provincial investments are urgently needed and are in keeping with the Canadian Federal Government's (2010) endorsement of the United Nations Declaration on the Rights of the Indigenous Peoples. ${ }^{93,94}$ New strategies, such as national-regional-and-community interventions, utilizing existing and new health and social authorities, and by building long-term institutional partnerships, are 
required to combat cancer risk disparities. ${ }^{95}$ More investments are also needed to address the ongoing legacy of colonization, as evidenced by poor living and socioeconomic conditions, lower educational attainment, and inadequate funding for services and infrastructure, which have directly and indirectly contributed to an increase in complex and difficult to treat chronic diseases in Canada's indigenous population. ${ }^{96,52}$ From a future research standpoint, we will investigate the complex social determinant pathways of cancer risk, and are updating what we know about the burden of cancer and trends over time, and looking into what improvements have been made in screening and prevention.

\section{Acknowledgments}

This research was supported by the Canadian Institutes of Health Research (\#AQC-83508) Dr Brenda Elias is supported by a CIHR New Investigator award and Dr Patricia Martens is supported by a CIHR/PHAC Applied Public Health Chair.

The Manitoba First Nations Regional Longitudinal Health Survey was a joint initiative of the Assembly of Manitoba Chiefs and the Manitoba First Nations Centre for Aboriginal Health Research (Dr Brenda Elias). The results and conclusions are those of the authors and no official endorsement by the Assembly of Manitoba Chiefs is intended or should be inferred.

\section{Disclosure}

The authors report no conflicts of interest in this work.

\section{References}

1. Aboriginal Affairs and Northern Development Canada Aboriginal Peoples and Communities webpage on the Internet. Ottawa. updated June 17, 2011. Available at: http://www.ainc-inac.gc.ca/ap/index-eng. asp. Accessed July 28, 2011.

2. Beauvais J. Health Status on Canadian Indian Reserves, 1974-1984. MSc thesis. McGill University, Montreal, QC; 1989.

3. Young TK, Choi NW. Cancer risks among residents of Manitoba Indian Reserves, 1970-1979. Can Med Assoc J. 1985;132:1269-1272.

4. Young TK. The Health of Native Americans: Towards a Biocultural Epidemiology. New York: Oxford University Press; 1994.

5. Young TK, Frank JW. Cancer surveillance in a remote Indian population in northwestern Ontario. Am J Public Health. 1983;73:515-520.

6. Gillis DC, Irvine J, Tan L, Chiu S, Liu L, Robson D. Cancer incidence and survival of Saskatchewan northerners and registered Indians (1967-1986). Proceedings of the 8th International Circumpolar Health Conference. Arctic Med Res. 1991;Suppl:447-451.

7. Morgan K, Laing LM. The incidence of cancer in Registered Indians of Alberta, 1974-1978. Chron Dis Can. 1981;2:33.

8. Health Canada. Trends in First Nations Mortality 1979-1993. Ottawa, ON; 1996.

9. Tjepkema M, Wilkins R, Senécal S, Guimond E, Penney C. Mortality of Metis and registered Indian adults in Canada: An 11-year follow-up study. Health Rep. 2009;20:31-51.
10. Rosenberg T, Martel S. Cancer trends from 1972-1991 for Registered Indians living on Manitoba Reserves. Int J Circumpolar Health. 1998;57(Suppl 1):391-398.

11. Marrett LD, Chaudhry M. Cancer incidence and mortality in Ontario First Nations, 1968-1991 (Canada). Cancer Causes Control. 2003;14: 259-268.

12. Lauchini R, Beapré M. Cancer incidence and mortality among aboriginal people living on reserves and northern villages in Québec, 1988-2004. Int J Circumpolar Health. 2008;67:445-451.

13. Kelly JJ, Lanier AP, Alberts S, Wiggins CL. Differences in cancer incidence among Indians in Alaska and New Mexico and US Whites, 1993-2002. Cancer Epidemiol Biomarkers Prev. 2006;15: $1515-1519$.

14. Espey DK, Wu XC, Swan J, et al. Annual report to the Nation on the status of cancer, 1975-2004, featuring cancer in American Indians and Alaska Natives. Cancer. 2007;110:2119-2152.

15. Suprmaniam R, Grindley H, Pulver LJ. Cancer mortality in Aboriginal people in New South Wales, Australia, 1994-2002. Aust NZ J Public Health. 2006;30:453-456.

16. Condon JR, Barnes A, Cunnigham J. Cancer in Indigenous Australians: a review. Cancer Causes Control. 2003;14:109-121.

17. Condon JR, Armstrong BK, Barnes T, Zhao Y. Cancer incidence and survival for Indigenous Australians in the Northern Territory. Aust NZ J Public Health. 2007;29:123-128.

18. Cunningham J, Rumbold AR, Zhang X, Condon JR. Incidence, aetiology, and outcomes of cancer in Indigenous peoples in Australia. Lancet Oncology. 2008;9:585-595.

19. Harwood M, Aldington S, Beasley R. Lung cancer in Maori: A neglected priority. NZ Med J. 2005;118:U1410.

20. Shaw C, Blakely T, Sarfati D, Fawcett J, Peace J. Trends in colorectal cancer mortality by ethnicity and socio-economic position in New Zealand, 1981-1999: one country, many stories. Aust NZ J Public Health. 2006;30:64-70.

21. Dachs GU, Currie MJ, McKenzie F, et al. Cancer disparities in indigenous Polynesian populations: Māori, Native Hawaiians, and Pacific people. Lancet Oncology. 2008;9:473-484.

22. Spitz MR, Bondy ML. Genetic susceptibility to cancer. Cancer. 1993;72:991-995.

23. Moore LE, Huang W, Hayes RB. Epidemiologic considerations to assess DNA methylation from environmental exposures to cancer. Ann NY Acad Sci. 2006;983:181-196.

24. Sutherland JE. Epigenetics and the environment. Ann NY Acad Sci. 2006;983:151-160.

25. Thun MJ, Henley SJ. Tobacco. In: Schottenfeld D, Fraumeni JF, editors. Cancer Epidemiology and Prevention. New York: Oxford University Press; 2006:217-242.

26. Marshall JR, Freudenheim J. Alcohol. In: Schottenfeld D, Fraumeni JF, editors. Cancer Epidemiology and Prevention. New York: Oxford University Press; 2006:243-258.

27. Rousseau MC, Parent ME, Pollak MN, Simitycki J. Diabetes mellitus and cancer risk in a population-based case control study among men from Montreal, Canada. Int J Cancer. 2006;118:2105-2109.

28. Huxley R, Ansary-Moghaddam A, Berrington de González A, Barzi F, Woodward M. Type-II diabetes and pancreatic cancer: a meta-analysis of 36 studies. Br J Cancer. 2005;92:2076-2083.

29. El-Serag HB, Hampel H, Javadi F. The association between diabetes and hepatacellular carcinoma: a systematic review of epidemiologic evidence. Clin Gastroenterol Hepatol. 2006;4:369-380.

30. Larsson SC, Orsini N, Brismar K, Wolk A. Diabetes mellitus and risk of bladder cancer: a meta-analysis. Diabetologia. 2006;49: 2819-2823.

31. Larsson SC, Orsini N, Wolk A. Diabetes mellitus and risk of colorectal cancer: a meta-analysis. J Natl Cancer Inst. 2005;97:1679-1687.

32. Bonovas S, Filioussi K, Tsantes A. Diabetes mellitus and risk of prostate cancer: a meta-analysis. Diabetologia. 2004;47:1071-1078.

33. Larsson SC, Mantzoros CS, Wolk A. Diabetes mellitus and risk of breast cancer: a meta-analysis. Int J Cancer. 2007;121:856-862. 
34. Friberg E, Orsini N, Matzoros CS, Wolk A. Diabetes mellitus and risk of endometrial cancer: a meta-analysis. Diabetologia. 2007;50: 1365-1374.

35. Barone BB, Yeh HC, Snyder CF, et al. Long-term all-cause mortality in cancer patients with pre-existing diabetes mellitus: a systematic review and meta-analysis. JAMA. 2008;300:2754-2764.

36. Chow WH, Gridley G, Fraumeni JF, Järvholm F. Obesity, hypertension and the risk of kidney cancer in men. New Engl J Med. 2000;343: 1305-1311.

37. McLaughlin JK, Lipworth L, Tarone RE, Blot WJ. Renal cancer. In: Schottenfeld D, Fraumeni JF, editors. Cancer Epidemiology and Prevention. New York: Oxford University Press; 2006:1087-1100.

38. Bianchini F, Kaaks R, Vainio H. Overweight, obesity and cancer risk. Lancet Oncol. 2002;3:565-574.

39. Renehan AG, Tyson M, Egger M, Heller RF, Zwahlen M. Body-mass index and incidence of cancer: a systematic review and meta-analysis of prospective observational studies. Lancet. 2008;371: 569-578.

40. Frezza EE, Wachtel MS, Chiriva-Internati M. Influence of obesity on the risk of developing colon cancer. Gut. 2006;55:285-291.

41. Stocks T, Lukanova A, Johansson M, et al. Components of the metabolic syndrome and colorectal cancer risk: A prospective study. Int J Obes (Lond). 2008;32:304-314.

42. Dossus L, Kaaks R. Nutrition, metabolic factors and cancer risk. Best Pract Res Clin Endocrinol Metab. 2008;22:551-571.

43. McTiernan A. Mechanisms linking physical activity with cancer. Nat Rev Cancer. 2008;8:205-211.

44. Friedenreich CM. Physical activity and cancer prevention: from observational to intervention research. Cancer Epidemiol Biomarkers Prev. 2001;10:287-301.

45. Kerlikowske K, Grady D, Rubin SM, Sandrock C, Ernster VL. Efficacy of screening mammography - a meta-analysis. JAMA. 1995;273: 149-154.

46. Parikh S, Brennan P, Boffetta. Meta-analysis of social inequality and the risk of cervical cancer. Int J Cancer. 2003;105:687-691.

47. CancerCare Manitoba. 2010 Community Health Assessment. Winnipeg, $\mathrm{MB} ; 2010$.

48. CancerCare Manitoba Incidence, Risk Factors and Future Cancer webpage on the Internet. Manitoba. copyrights 2000-2011. Available at: http://www.cancercare.mb.ca/home/about_us/future_cancer_rates. Accessed on September 13, 2011.

49. First Nations Centre (NAHO) First Nations Regional Longitudinal Health (RHS) Survey 2002/03: Results for adults, youth and children living in First Nations communities. Ottawa, ON: National Aboriginal Health Organization; 2005.

50. O’Neil J, Elias B, Leader A, Wastesicoot J, Manitoba First Nation Regional Health Steering Committee. Manitoba First Nations Regional Health Survey: Final Report. Joint Initiative of the Assembly of Manitoba Chiefs, Manitoba Keewatinowi Okimakanak and the Northern Health Research Unit, University of Manitoba; 1998.

51. Sarkar J, Lix LM, Bruce S, Young TK. Ethnic and regional differences in prevalence and correlates of chronic diseases and risk factors in northern Canada. Prev Chronic Dis. 2010;7:A13.

52. Elias B. Social Environment and the Health of Manitoba First Nations Communities. Dissertation. University of Manitoba, Winnipeg, MB; 2003.

53. Statistics Canada. Smokers, by sex, provinces and territories. In: Health Indicators 2003; Catalogue No. 82-221-XWE.

54. Thommasen HV, Hanlon N, Thommasen C, Zhang W. Alcohol drinking habits and community perspectives on abuse in the Bella Colla Valley. Can J Rural Med. 2006;11:15-22.

55. Doshi SF Jiles R. Health Behaviors among American Indian/Alaska native women, 1998-2000 BFRSS. J Women's Health (Larchmt). 2006;15:919-927.

56. Anand SS, Yusuf S, Vuksan V, et al. Differences in risk factors, atherosclerosis, and cardiovascular disease among ethnic groups in Canada: The Study of Health Assessment Risk in Ethnic groups (SHARE). Lancet. 2000;356:279-284.
57. Anand SS, Yusuf S, Jacobs R, Davis AD, Yi Q, Gerstein H, et al. Risk factors, atherosclerosis, and cardiovascular disease among Aboriginal people in Canada: The Study of Health Assessment and Risk Evaluation in Aboriginal Peoples (SHARE-AP). Lancet. 2001;358:1147-1153.

58. Price RA, Charles MA, Pettitt DJ, Knowler WC. Obesity in Pima Indians: large increases among post-World War II birth cohorts. Am J Phys Anthropol. 1993;82:473-479.

59. Gray RS, Fabsitz RR, Cowan LD, Lee ET, Jablonski TK, Howard BV. Relation of generalized and central obesity to cardiovascular risk factors and prevalent chronic heart disease in a sample of American Indians: The Strong Heart Study. Int J Obes Relat Metab Disord. 2000;24: 849-860.

60. Welty TK, Lee ET, Yeh J, et al. Cardiovascular disease risk factors among American Indians: The Strong Heart Study. Am J Epidemiol. 1995;142:269-287.

61. Young TK, Reading J, Elias B, O’Neil J. Type-2 diabetes in Canada's First Nations: status of an epidemic in progress. CMAJ. 2000;163: 561-566.

62. Green C, Blanchard JF, Young TK, Griffith J. The epidemiology of diabetes in the Manitoba First Nations population: Current patterns and comparative trends. Diabetes Care. 2003;26:1993-1998.

63. Dyck R, Osgood N, Lin TH, Gao A, Stang MR. Epidemiology of diabetes mellitus among First Nations and non-First Nations. CMAJ. 2010;182:781-789.

64. Public Health Agency of Canada. Report from the Canadian Chronic Disease Surveillance System: Hypertension in Canada, 2010. Ottawa, ON: Public Health Agency of Canada; 2010.

65. Amankwah E, Campbell NR, Maxwell C, Onysko J, Quan H. Why some adult Canadians do not have blood pressure measured. J Clin Hyperten. 2007;9:944-951.

66. Ley SH, Harris SB, Mamakeesick M, et al. Metabolic syndrome and its components as predictors of incident type 2 diabetes mellitus in an aboriginal community. CMAJ. 2009;180:617-624.

67. Hanley AJG, Harris SB, Mamakeesick M, et al. Complications of type 2 diabetes among Aboriginal Canadians. Diabetes Care. 2005;28:2054-2057.

68. Pollex RL, Hanley AJ, Zinman B, Harris SB, Khan HM, Hegele RA. Metabolic syndrome in aboriginal Canadians: prevalence and genetic associations. Atherosclerosis. 2006;184:121-129.

69. Sellers E, Eisenbarth G, Young TK, Dean HJ. Diabetes-associated autoantibodies in aboriginal children. Lancet. 2000;355:1145.

70. Dean HJ, Sellers EA. Diabetic ketoacidosis: a complication of type 2 diabetes in Canadian aboriginal youth. Diabetes Care. 2000;23: 1202-1204.

71. Wahi G, Zorzi A, Macnab A, Panagiotopoulos C. Prevalence of type 2 diabetes, obesity and the metabolic syndrome among Canadian First Nations children in a remote Pacific coast community. Paediatr Child Health. 2009;14:79-83.

72. Kaler SN, Ralph-Campbell K, Pohar S, King M, Laboucan CR, Toth EL. High rates of the metabolic syndrome in a First Nations community in western Canada: Prevalence and determinants in adults and children. Int J Circumpolar Health. 2006;65:389-402.

73. Zorzi A, Wahi G, Macnab AJ, Panagiotopoulos C. Prevalence of impaired glucose tolerance and the components of metabolic syndrome in Canadian Tsimshian Nation youth. Can J Rural Med. 2009; 14:61-67.

74. Che J, Chen J. Food insecurity in Canadian households. Health Reports. 2001;12:11-22.

75. Kawachi I, Kroneke C. Socioeconomic disparities in cancer incidence and mortality. In: Schottenfeld D, Fraumeni JF, editors. Cancer Epidemiology and Prevention. New York: Oxford University Press; 2006:174-188.

76. Young TK, Kliewer E, Blanchard J, Mayer T. Monitoring disease burden and preventative behavior with data linkage: cervical cancer among aboriginal people in Manitoba, Canada. Am J Public Health. 2000;90:1466-1468. 
77. Calam B, Norgrove L, Brown D, Wilson MA. Pap screening clinics with native women in Skidegate Haida Gwaii: Need for innovation. Can Fam Physician. 1999;45:355-360.

78. Hwi L, Ting J. Cervical cancer screening rates of Reserve and NonReserve women served by the Ste. Rose du Lac Clinic in the East Parkland Regional Health Authority. University of Manitoba SWEAT Program - Medicine Year 1; 2001.

79. Hislop TG, Clarke HG, Deschamps M, et al. Cervical cytology screening: how can we improve rates among First Nations in urban British Columbia? Can Fam Physician. 1996;42:1701-1708.

80. Gupta S, Roos LL, Wald R, Traverse D, Dahl M. Delivering equitable care: comparing preventive service in Manitoba. Am J Public Health. 2000;93:2066-2092.

81. CancerCare Manitoba. Community Health Assessment. Winnipeg, MB; 2005

82. Cooke M, Mitrou F, Lawrence D, Guimond E, Beavon D. Indigenous well-being in four countries: An application of the UNDP'S Human Development Index to indigenous peoples in Australia, Canada, New Zealand, and the United States. BMC Int Hum Rights. 2007;7:9.

83. McHardy M, O'Sullivan E. First Nations community wellbeing in Canada: The community well-being index (CWB), 2001. Ottawa, ON: Strategic Research and Analysis Directorate, Indian and Northern Affairs Canada; 2004

84. Martens P, Fransoo R. The Need to Know Team, Burland E, Prior H, Burchill C, et al. What Works? A First Look at Evaluating Manitoba's Regional Health Programs and Policies at the population level. Winnipeg, MB: Manitoba Centre for Health Policy; 2008.

85. Chiu LF. Inequalities of access to cancer screening: A literature review. Sheffield, UK: National Health Service Cancer Screening Programmes; 2003.

86. Newell S, Girgis A. The accuracy of self-reported health behaviors and risk factors relating to cancer and cardiovascular disease in the general population: a critical review. Am J Prev Med. 1999;17:211-229.
87. Steele CB, Cardinez CJ, Richardson LC, Tom-Orme L, Shaw KM Surveillance for health behaviors of American Indians and Alaska Natives - Findings from the behavioral risk factor surveillance system, 2000-2006. Cancer. 2008;113(5 Suppl):1131-1141.

88. Bramley D, Hebert P, Tuzzio L, Chassin M. Disparities in indigenous health: a cross-country comparison between New Zealand and the United States. Am J Public Health. 2005;95(5):844-850.

89. Trewin D, Madden R. The health and welfare of Australia's Aboriginal and Torres Strait Islander Peoples. Canberra, ACT: Australian Bureau of Statistics, Australian Institute of Health and Welfare; 2005.

90. Burke V, Zhao Y, Lee AH, Hunter E, Spargo RM, Gracey M, et al. Health-related behaviors as predictors of mortality and morbidity in Australian Aborigines. Prev Med. 2007;44:135-142.

91. Paradis G, Lévesque L, Macaulay AC, et al. Impact of a diabetes prevention program on body size, physical activity, and diet among Kanien'kehá:ka (Mohawk) children 6 to 11 years old: 8-year results from the Kahnawake Schools Diabetes Prevention Project. Pediatrics. 2005;115:333-339.

92. Foliaki S, Pearce N. Changing patterns of ill health for indigenous peoples. BMJ. 2003;327:406-407.

93. United Nations General Assembly. The UN Declaration on the Rights of Indigenous Peoples. New York: United Nations; 2007. http://www un.org/esa/socdev/unpfii/en/drip.html. Accessed June 15, 2010.

94. United Nations Declaration on the Rights of the Indigenous Peoples Adopted by the General Assembly 12; Sep 2007. http://www. un.org/esa/socdev/unpfii/en/declaration.html. Accessed September 5, 2011.

95. Jones L, Chilton JA, Hajek RA, Iammarino NK, Laufman L. Between and within: International perspectives on cancer and health disparities J Clin Oncol. 2006;24:2204-2008.

96. Gracey M, King M. Indigenous health part 1: Determinants and disease patterns. Lancet. 2009;374:65-75.
International Journal of General Medicine

\section{Publish your work in this journal}

The International Journal of General Medicine is an international, peer-reviewed open-access journal that focuses on general and internal medicine, pathogenesis, epidemiology, diagnosis, monitoring and treatment protocols. The journal is characterized by the rapid reporting of reviews, original research and clinical studies across all disease areas.

\section{Dovepress}

A key focus is the elucidation of disease processes and management protocols resulting in improved outcomes for the patient.The manuscript management system is completely online and includes a very quick and fair peer-review system. Visit http://www.dovepress.com/ testimonials.php to read real quotes from published authors. 